\title{
Penerapan Model Pembelajaran Cooperative learning Tipe Think PAIR SHARE PADA MATERI LiSTRIK DINAMIS UNTUK MENINGKATKAN HASIL BELAJAR SISWA KELAS XI TKR1 SMK NEGERI 2 TARAKAN
}

\author{
Kule $^{1)}$, Hengki Wijaya ${ }^{2)}$ \\ 1) SMK Negeri 2 Tarakan \\ E-mail: kule66.0602@gmail.com \\ 2) Pascasarjana Ilmu Pendidikan Universitas Negeri Makassar \\ E-mail: hengkilily1988@gmail.com
}

\begin{abstract}
Abstrak. Tujuan penelitian ini adalah untuk memperoleh deskripsi peningkatan hasil belajar siswa melalui model pembelajaran kooperatif tipe Think Pair Share (TPS) dengan materi pelajaran listrik dinamis di kelas XI TKR1 SMK Negeri 2 Tarakan. Rancangan penelitian tindakan kelas ini mengacu pada desain penelitian Kemmis dan Mc. Taggart yakni (1) perencanaan (planning), (2) pelaksanaan tindakan (acting), (3) observasi (observasing) dan (4) refleksi (reflecting). Penelitian ini dilakukan dalam dua siklus. Tiap siklus terdiri dari tiga kali pertemuan. Hasil penelitian menunjukkan bahwa terjadi peningkatan hasil belajar siswa melalui model pembelajaran kooperatif tipe think pair share (TPS) materi pelajaran listrik dinamis dengan kegiatan: (1) tahap think, siswa diberi peluang menyelesaikan masalah listrik dinamis berupa muatan atom dalam suatu unsur, (2) tahap pair, siswa bersama pasangannya menalar keterkaitan antara muatan inti atom dengan elektron, (3) tahap share, siswa bersama-sama kelompok mengomunikasikan hasil temuannya di depan kelas tentang gerakan elektron dapat menimbulkan muatan listrik dinamis. Hasil belajar fisika dengan menggunakan Think Pair Share mengalami peningkatan rata-rata hasil belajar siswa dari angka 72,90\% pada siklus I menjadi $81,18 \%$ pada siklus II.
\end{abstract}

Kata Kunci: Peningkatan Hasil Belajar; Model Pembelajaran Kooperatif Tipe Think Pair Share (TPS)

\section{Pendahuluan}

Model pembelajaran kooperatif tipe Think Pair Share adalah salah satu model kooperatif yang sesuai digunakan dalam pembelajaran fisika. Perangkat pembelajaran fisika berorientasi model pembelajaraan kooperatif tipe think pair square dalam meningkatkan keterampilan sosial siswa dan ketuntasan belajar siswa layak digunakan dalam pembelajaran [1].

Tipe Think Pair Share adalah metode yang cukup sederhana, fleksibel, dan ekonomis. Pekerjaan awal untuk pelatihan dalam strategi pembelajaran umumnya mudah dan tidak membutuhkan waktu yang lama dari para instruktur [2] [3] [4]. Strategi pembelajaran dapat dengan mudah dilakukan dengan kelompok kecil atau kelompok besar dan digunakan selama tahap pengajaran dan pembelajaran dalam banyak disiplin ilmu [5] [6] [7].

Penggunaan model pembelajaran tipe think pair square (TPS) terbukti meningkatkan hasil belajar sosiologi dalam ketuntasan belajar. Pada akhir siklus I, siswa yang mencapai ketuntasan belajar sebanyak 72,41\% (21 anak), dan siswa yang belum tuntas sebanyak 27,59\% (8 anak), sedangkan pada akhir siklus II, sebanyak 93,10\% (27 anak) dan sebanyak $6,89 \%$ (2 anak) belum mencapai ketuntasan belajar [8].

Penelitian yang lain adalah dengan menerapkan model pembelajaran tipe Think Pair Share berbasis pemecahan masalah diharapkan dapat meningkatkan keterampilan berpikir tingkat tinggi siswa yang berdampak pada meningkatnya pemahaman konsep siswa dan prestasi belajar siswa sehingga siswa akan merasakan dan memahami makna dari pembelajaran yang dilakukannya [9] [10].

Penelitian penulis ini memberikan gambaran kondisi pembelajaran fisika di kelas XI TKR1 SMK Negeri 2 Tarakan, selain menjadi mata pelajaran adaptif, siswa harus mencapai kriteria ketuntasan minimal (KKM) yang dipersyaratkan oleh sekolah dan industri yakni di atas 75. Kondisi pembelajaran yang dialami peneliti selama ini hanya 10 siswa saja yang telah mencapai ketuntasan sedangkan yang lainnya tidak tercapai sehingga diperlukan cara untuk meningkatkan hasil belajar sehingga siswa tuntas dalam pembelajaran [11] [12].

Dengan adanya pengalaman peneliti dalam pembelajaran serta observasi yang dilakukan peneliti sebagai guru mata 


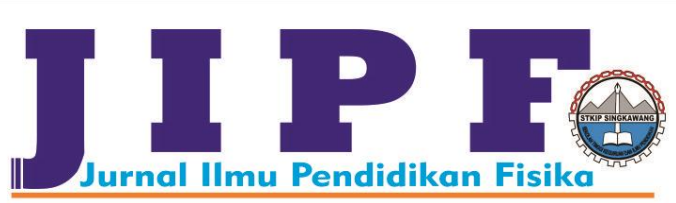

pelajaran di kelas XI TKR1 SMK Negeri 2 Tarakan, ada beberapa kemungkinan penyebab rendahnya hasil belajar siswa antara lain: (1) pembelajaran masih berpusat pada guru sebagai satu-satunya sumber belajar, (2) komunikasi yang terjalin hanya satu arah yakni dari guru saja sehingga siswa pasif, (3) metode pembelajaran yang digunakan guru kurang bervariasi sehingga pembelajaran terkesan sangat monoton, sehingga diperlukan tindakan guru dalam upaya meningkatkan hasil belajar siswa melalui penelitian tindakan [13].

Muktiyani dan Sulistiawan [14] [15] menjelaskan kelebihan model pembelajaran kooperatif tipe Think Pair Share (TPS) sebagai berikut: 1) Siswa berperan aktif selama proses pembelajaran berlangsung; 2) Dengan memberi kesempatan kepada siswa melalui kelompok untuk siswa mengkontruksi pengetahuan; 3) Dapat meningkatkan kemampuan siswa untuk belajar sendiri; (4) Memotivasi siswa untuk belajar.

Tujuan kegiatan Think Pair Share adalah untuk membantu siswa menyelinapkan informasi, dan hasilnya menunjukkan bahwa Think Pair Share lebih baik digunakan ketika tujuannya lebih dari sekadar fakta belajar, kecuali penilaian formatif sama dengan sumatif penilaian. Think Pair Share paling baik digunakan ketika tujuannya adalah berpikir tingkat tinggi, dan pendekatan desain mundur, seperti yang dijelaskan oleh Wiggins dan McTighe [6] [16] adalah yang terbaik untuk tujuan ini. Misalnya, pertanyaan penilaian formatif dan sumatif dapat mencakup petunjuk yang meminta siswa untuk menjelaskan alasan mereka dan menerapkan pengetahuan mereka ke skenario kehidupan nyata.

Rumusan masalah yang menjadi fokus dalam penelitian tindakan ini adalah bagaimana model pembelajaran kooperatif tipe think pair share (TPS) pada materi listrik dinamis di kelas XI TKR1 SMK Negeri 2 Tarakan dapat meningkatkan hasil belajar fisika? Tujuan penelitian ini adalah meneliti terjadinya peningkatan hasil belajar siswa melalui model pembelajaran kooperatif tipe think pair share pada materi listrik dinamis di kelas XI TKR1 SMK Negeri 2 Tarakan.

\section{Metode}

Desain penelitian ini mengacu pada model penelitian tindakan kelas yang dikembangkan oleh Kemmis dan Mc. Taggart [17] [18]. Penelitian dilaksanakan dalam dua siklus dan setiap siklus meliputi kegiatan sebagai berikut: 1) perencanaan; 2) pelaksanaan tindakan; 3) pengamatan; 4) refleksi.

Waktu penelitian tindakan kelas ini dari bulan Juli 2016 sampai dengan Oktober 2016 dan melibatkan seluruh siswa kelas XI TKR1 sebanyak 30 orang, yang terdiri dari 4 orang perempuan dan 26 orang laki-laki dan lokasi penelitian dilaksanakan di SMK Negeri 2 Tarakan dengan alamat Jalan Aki Balak RT. 020, Kota Tarakan, Provinsi Kalimantan Utara. Dipilihnya sekolah ini karena peneliti menjadi guru di tempat tersebut, sehingga hasil penelitian yang dihasilkan akan menjadi rujukan peneliti untuk memperbaiki metode pembelajaran selanjutnya.

Kriteria keberhasilan tindakan pada kegiatan penelitian ini ditentukan oleh keberhasilan siswa dalam proses pembelajaran fisika melalui metode think pair share dengan teknik analisis data yang digunakan adalah analisis deskriptif berdasarkan hasil tes akhir pembelajaran dengan menggunakan distribusi frekuensi dan persentase. Nilai yang diperoleh selanjutnya dikelompokkan menjadi lima kategori. Kriteria untuk menentukan hasil belajar siswa dikenakan teknik kategorisasi sebagai berikut: (a) Skor 0-44 dikategorikan sangat rendah, (b) Skor 45-64 dikategorikan rendah, (c) Skor 65-74 dikategorikan sedang, (d) Skor 75-84 dikategorikan tinggi, dan (e) Skor 85-100 dikategorikan sangat tinggi [19].

Sedangkan indikator keberhasilan dalam penelitian ini adalah meningkatnya skor rata-rata dan ketuntasan hasil belajar siswa telah mencapai skor $\geq 75$ dan ketuntasan klasikal tercapai jika minimal $80 \%$ mencapai nilai $\geq 75$ [20] [21] [22].

\section{HASIL DAN PEMBAHASAN}

Pelaksanaan penelitian menggunakan metode think pair share melalui langkah-langkah (a) siswa dikelompokkan menjadi beberapa kelompok, (b) setiap kelompok terdiri dari 4-5 orang, (c) siswa diberikan soal yang sama, (d) setiap siswa berpikir dan menalar jawaban (think), (e) siswa mendiskusikan dengan teman satu kelompok tentang hasil yang diperoleh (pair), dan (f) kelompok yang sudah selesai mempresentasikan hasil yang diperoleh kepada semua kelompok lainnya (share) [19].

Hasil penelitian yang telah dilakukan pada siklus I adalah sebagai berikut, (a) siswa yang mendapat nilai lebih besar dari 75 pada pertemuan pertama 15 orang atau $50 \%$ dan pertemuan kedua bertambah menjadi 16 orang atau 53,33\%, serta pertemuan ketiga menjadi 27 orang atau $90 \%$, dan (b) berarti siswa yang mendapat nilai di atas 75 sebanyak $90 \%$, dan ratarata secara klasikal adalah 77,90 sehingga belum termasuk mencapai ketuntasan secara klasikal sehingga perlu dilanjutkan ke siklus II. Hasil penelitian siklus I terlihat dalam Tabel 1 berikut ini.

TABEL I

Ketuntasan Hasil Belajar SiKLUs I

\begin{tabular}{cccc}
\hline Kegiatan & $<\mathbf{7 5}$ & $>\mathbf{7 5}$ & Rata-rata \\
\hline Pertemuan 1 & 15 & 15 & 67,90 \\
\hline Pertemuan 2 & 14 & 16 & 72,90 \\
\hline Pertemuan 3 & 3 & 27 & 77,90 \\
\hline
\end{tabular}

Sedangkan grafik ketuntasan hasil belajar siklus I dapat dilihat pada Grafik 1 berikut ini.

Peningkatan Hasil Belajar Siswa Siklus I Pertemuan Mengajar 1, 2 dan 3

a Pertemuan 1 = Pertemuan 2 =Pertemuan 3

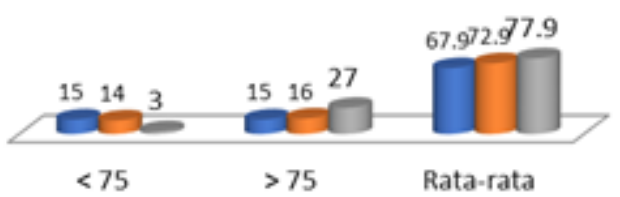

Gambar 1 Grafik Ketuntasan Hasil Belajar Siklus I 


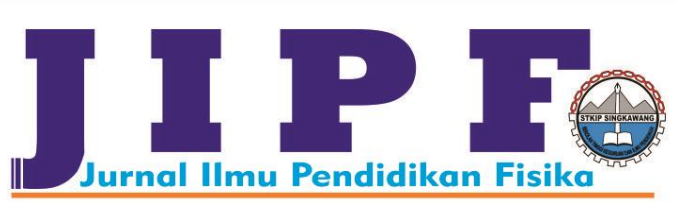

Pelaksanaan kegiatan belajar mengajar pada siklus I ini masih terdapat kekurangan, sehingga perlu adanya perbaikan untuk dilakukan pada siklus II. Guru perlu lebih kreatif dalam melaksanakan langkah-langkah pembelajaran yang tepat dan mengajak siswa untuk terlibat langsung dalam setiap kegiatan yang akan dilakukan.

Hasil belajar pada Siklus II diuraikan sebagai berikut: (a) siswa yang mendapat nilai > 75 pada pertemuan keempat adalah 28 orang atau 93,33\%, (b) siswa yang mendapat nilai di atas 75 pada pertemuan ke lima adalah 28 orang atau $93,33 \%$, (c) siswa yang mendapatkan nilai di atas 75 pada pertemuan keenam adalah 29 orang atau 96,67\% dengan ratarata siklus II adalah 81,18 dan dengan melihat hasil yang diperoleh hingga siklus II pertemuan keenam maka hasil penelitian telah mencapai ketuntasan minimal yakni di atas $80 \%$ sehingga penelitian dihentikan. Untuk jelasnya dapat dilihat pada Tabel 2 berikut ini.

TABEL II

KeTUNTASAN HASIL BELAJAR SIKLUS II

\begin{tabular}{cccc}
\hline Kegiatan & $<\mathbf{7 5}$ & $\boldsymbol{> 7 5}$ & Rata-rata \\
\hline Pertemuan 4 & 2 & 28 & 78,57 \\
\hline Pertemuan 5 & 2 & 28 & 80,07 \\
\hline Pertemuan 6 & 1 & 29 & 81,18 \\
\hline
\end{tabular}

Sedangkan grafik ketuntasan rata-rata pertemuan 4, 5 dan 6 siklus II sebagai berikut.

Peningkatan Hasil Belajar

Siklus II Pertemuan Mengajar 4,5 dan 6

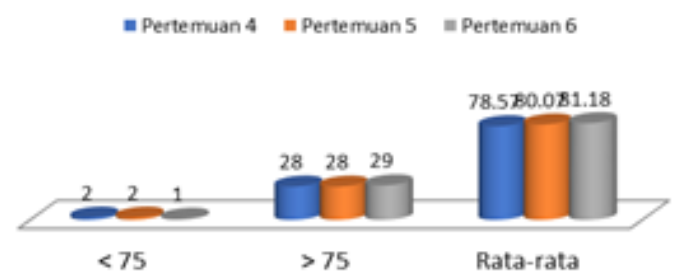

Gambar 2 Grafik Ketuntasan Hasil Belajar Siklus II

Rata-rata nilai yang diperoleh dalam penelitian dengan metode think pair share siswa pada siklus II adalah (a) hasil pembelajaran pada pertemuan 4 adalah 78,57, (b) hasil pembelajaran pada pertemuan 5 adalah 80,07, (c) hasil pembelajaran pada pertemuan 6 adalah 81,90 sehingga (d) rerata peningkatan hasil pembelajaran pertemuan 4,5 dan 6 adalah 80,18 .

Pada siklus II siswa yang memperoleh nilai sama atau melebihi nilai KKM 75 adalah 29 orang atau 96,67\% sehingga siswa secara klasikal telah mencapai indikator keberhasilan yakni $80 \%$, sedangkan ada 1 siswa yang belum mencapai ketuntasan akan dilakukan perbaikan tersendiri dengan pemberian remedial.

Berdasarkan analisis data yang telah dipaparkan di atas, maka dapat dijelaskan bahwa sebelum diterapkan metode think pair share nampak siswa sangat pasif dalam pembelajaran dengan tingkat hasil belajar yang rendah dan
Jurnal Ilmu Pendidikan Fisika

Volume 3 Number 2 month September 2018. Page 47-51 p-ISSN: 2477-5959 e-ISSN: 2477-8451

setelah diterapkannya metode think pair share maka hasil belajar siswa sangat meningkat.

Peningkatan hasil belajar fisika dengan mengunakan metode think pair share mengalami peningkatan dari setiap siklus. Peningkatan rata-rata kelas hasil belajar siswa untuk penelitian adalah $72,90 \%$ pada siklus I dan siklus II menjadi $81,18 \%$, sebagaimana tercantum dalam Grafik 3 berikut ini.

\section{Peningkatan Rata-rata Hasil Belajar Siklus I dan Siklus II}

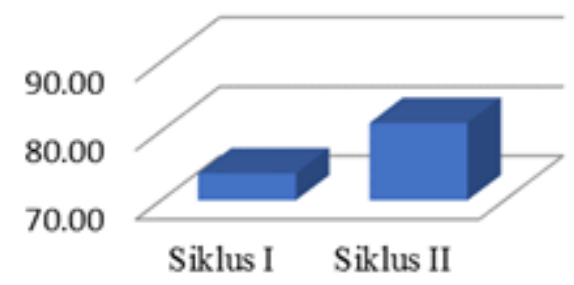

Gambar 3 Peningkatan Rata-Rata Hasil Belajar Siklus I dan Siklus II

Dengan memperhatikan paparan data dan analisis data, maka terjadi peningkatan hasil belajar fisika dengan menggunakan metode think pair share yakni meningkatnya hasil belajar siswa pada kompetensi listrik dinamis.

Kemampuan dalam think atau berpikir diukur dengan tes akhir pembelajaran dan observasi selama pembelajaran semakin meningkat. Kemampuan berdiskusi (pair) siswa yang diperoleh melalui lembar pengamatan menunjukkan skor lebih baik dibandingkan pada saat tes awal, hal ini disebabkan karena, (a) siswa lebih mudah menyampaikan pendapatnya dalam bentuk lisan dibanding tulisan (b) keaktifan siswa dalam proses belajar mendorong siswa lain untuk terlibat dalam pembelajaran, (c) kepercayaan diri siswa muncul pada saat berbagi (share) langsung dengan teman-temannya.

Tindakan siklus I hasil belajar fisika dengan menggunakan metode think pair share sudah mengalami peningkatan yang ditandai dengan hasil belajar siswa, demikian pula siswa mulai dapat membangun kerja sama tanpa memperhatikan memilih teman.

Penerapan metode think pair share sering dilakukan pada kegiatan pembelajaran sehingga siswa dapat berinteraksi dan menjalin keakraban secara lebih dini serta dapat menyesuaikan diri dengan teman kelompoknya, karena tercipta keakraban di antara anggota kelompok siswa merupakan faktor pendukung terbentuknya suasana belajar yang dinamis. Berkaitan dengan hal ini Arikunto [23] menyatakan bahwa agar hubungan kawan dapat memberi pengaruh yang positif atau konstruktif, mereka (subjek) harus mengusahakan terjadinya suasana saling memiliki, saling menerima, saling membantu dan saling memperhatikan satu sama lain.

Sifat atau karakter yang dimiliki oleh individu ternyata mempengaruhi aktivitas dalam pembelajaran. Sebagaimana terjadi pada tindakan siklus I walaupun pembelajaran sudah berjalan cukup baik namun secara individu masih ada siswa yang hasil belajarnya masih rendah. Hal ini diperkuat dengan pandangan Slavin [24] dan Johnson \& Johnson dalam Trianto 
[25] [26] bahwa dalam belajar kelompok kecil, anggotaanggota kelompok harus saling memberi bantuan penjelasan dalam penguasaan materi, tetapi ini tidak mungkin terjadi bila anggota kelompok tidak mampu atau tidak mau mengemukakan pendapatnya apa yang diperlukan (karena diam atau malu bertanya).

Upaya yang dilakukan guru dengan mengadakan pendekatan dan dorongan secara khusus terhadap siswa maka membuahkan hasil yang baik terlihat pada hasil siklus II siswa yang kurang berani dan kurang aktif pada siklus I. Nampak pada siklus II sangat antusias dalam mengajukan pertanyaan, menjawab pertanyaan bahkan mengajukan pendapat atau idenya. Keberhasilan tersebut juga ditunjang oleh perluasan ruang lingkup pembelajaran menjadi diskusi kelas pada siklus II.

Sampai dengan tindakan siklus II hasil belajar masuk dalam kategori baik siswa dipandang telah behasil dalam penerapan metode think pair share untuk meningkatkan hasil belajar siswa sebagaimana yang diharapkan oleh guru.

Analisis terhadap hasil tes (evaluasi) yang diberikan setelah pelaksanaan tindakan mengalami peningkatan dari siklus I ke siklus II menunjukkan bahwa di mana siswa yang mendapatkan nilai $>75$ pada awal penelitian hanya $50 \%$ dan mengalami peningkatan pada siklus II menjadi 96,67\%.

Dari uraian di atas menunjukkan bahwa peningkatan hasil belajar fisika dengan menggunakan metode think pair share tercapai. Hal ini diperkuat dari pendapat Winkel dalam Trianto [20] yang mengemukakan bahwa "hasil belajar merupakan kemampuan maksimal yang dicapai seseorang dalam usaha yang menghasilkan pengetahuan. Dengan belajar seseorang memiliki kemampuan, pengetahuan, dan keterampilan tertentu sesuai dengan pengetahuan yang dialaminya. Siswa yang telah mengalami pembelajaran diharapkan memiliki pengetahuan dan keterampilan baru serta perbaikan sikap sebagai hasil dari pembelajaran yang dialami siswa tersebut.

\section{KESIMPULAN DAN SARAN}

\section{A. Simpulan}

Keaktifan siswa dalam mengikuti pembelajaran dengan think pair share, yakni dalam memikirkan, mendiskusikan pesan dan menyampaikan pesan kepada teman sekelas sesuai prinsip Think Pair Share pada siklus I rata-rata masih rendah dan nilainya masih belum mencapai batas ketuntasan belajar karena siswa belum sepenuhnya menggunakan prinsip think pair share. Namun pada siklus II mengalami peningkatan yang signifikan. Melalui perbaikan dan diskusi dengan observer, maka siswa dapat lebih menguasai konsep, menyampaikan materi pesan sesuai think pair share pada sesama siswa. Aktivitas siswa yang meliputi perhatian, partisipasi dan pemahaman pada siklus I masih kurang hingga pada siklus II semakin baik sehingga metode pembelajaran think pair share ini sangat membantu meningkatkan hasil belajar siswa.
Jurnal Ilmu Pendidikan Fisika

Volume 3 Number 2 month September 2018. Page 47-51 p-ISSN: 2477-5959 e-ISSN: 2477-8451

\section{B. Saran}

Penelitian tindakan kelas ini dapat dilakukan atau diuji coba lebih lanjut untuk materi pembelajaran yang lain sehingga dapat menunjukkan hasil yang lebih baik, sehingga diberikan saran-saran sebagai berikut, (a) kepada guru mata pelajaran fisika kelas XI SMK agar dapat menerapkan metode think pair share dalam pembelajaran, karena sangat membantu siswa dalam memahami dan mengerti materi pembelajaran, (b) kepada Kepala Sekolah yang melakukan salah satu fungsinya sebagai supervisor maka diharapkan mampu melakukan supervisi bagi guru-guru di sekolahnya sehingga dapat diketahui kesulitan yang dihadapi dan memberikan alternatif penyelesaian masalah yang dihadapi guru, dan (c) kepada Dinas Pendidikan Kota Tarakan supaya terus menerus melakukan motivasi kepada sekolah untuk melakukan penelitian yang dapat mengembangkan think pair share bagi guru pemula dalam pembelajaran sehingga hasil lulusan sekolah yang bermutu.

\section{Daftar Pustaka}

[1] Frisky, B., Wasis, A., Supardi, I. (2015). Pengembangan Perangkat Pembelajaran Fisika Berorientasi Model Pembelajaran Kooperatif Think Pair Square Dalam Meningkatkan Keterampilan Sosial dan Ketuntasan Belajar Siswa. JPPS (Jurnal Pennelitian Pendidikan Sains), 4(2): 579-590.

[2] Irhamna, Rosdianto, H., \& Murdani, E. (2017) Penerapan Model Learning Cycle 5E untuk Meningkatkan Keterampilan Berpikir Kritis Siswa Pada Materi Fluida Statis Kelas VIII. Jurnal Fisika Flux, 14(1): 61-64.

[3] Nadiya, Rosdianto, H., \& Murdani, E. (2016). Penerapan Model Pembelajaran Group Investigation (GI) untuk Meningkatkan Keterampilan Berpikir Kritis Siswa pada Materi Gerak Lurus Kelas X. JIPF (Jurnal Ilmu Pendidikan Fisika), 1(2): 49-51.

[4] Rosdianto, H., Murdani, E., \& Hendra. (2017). Implementasi Model Pembelajaran POE (Predict Observe Explain) Untuk Meningkatkan Pemahaman Konsep Siswa Pada Materi Hukum Newton. Jurnal Pendidikan Fisika, 6(1): 55-57.

[5] Gok, T. (2018). The evaluation of conceptual learning and epistemological beliefs on physics learning by thinkpair-share. Journal of Education in Science, Environment and Health (JESEH), 4(1): 69-80. DOI:10.21891/jeseh.387489

[6] Prahl, K. (2017). Best practices for the think-pair-share active-learning technique. The American Biology Teacher, 79(1): 3-8.

[7] Raba, A.A.A. (2017). The influence of think-pair-share (TPS) on improving students' oral communication skills in EFL classrooms. Creative Education, 8: 12-23.

[8] Zuraida. (2017). Penggunaan Model Pembelajaran Tipe Tps Dalam Upaya Meningkatkan Hasil Belajar Sosiologi Materi Pokok Bentuk-Bentuk Konflik Sosial Pada Siswa. Jurnal Visipena, 8(2): 295-310. 
[9] Sumarli. (2018). Analisis Model Pembelajaran Tipe Think-Pair-Share Berbasis Pemecahan Masalah Terhadap Keterampilan Berpikir Tingkat Tinggi Siswa. JIPF (Jurnal Ilmu Pendidikan Fisika), 3(1): 8-13.

[10] Rosdianto, H. (2017). Students Conceptual Understanding through Generative Learning Model in Topic "Light". JPI (Jurnal Pendidikan Indonesia), 6(2): 259-262.

[11] Hasil tes akhir pembelajaran siswa kelas XI TKR1 SMK Negeri 2 Tarakan tahun 2017.

[12] Siradjuddin, Rosdianto, H., \& Sulistri, E. (2018). Penerapan Model REACT Untuk Meningkatkan Keterampilan Proses Sains Siswa Pada Materi Arus Listrik. Jurnal Pendidikan Fisika dan Keilmuan (JPFK), 4(1): 17-22.

[13] Iskandar. (2009). Penelitian Tindakan Kelas. Jakarta: Gaung Persada (GP) Press.

[14] Rita Novita. (2014). Efektivitas Model Pembelajaran Kooperatif Tipe Think Pair Share (TPS) Pada Materi Trigonometri Di Kelas XI IA1 SMA Negeri 8 Banda Aceh. Jurnal Visipena, 5(1): 128-135.

[15] Muktiyani, \& Sulistiawan, A. (2004). Pembelajaran Kooperatif Tipe TPS (Think-Pair-Share) untuk Materi Pokok Statistik dan Peluang di Kelas IX SMP. Program Studi Pendidikan Matematika PPP-UNESA. Surabaya.

[16] Wiggins, G., \& McTighe, J. (1988). Understanding by Design. Alexandria. VA: Association for Supervision and Curriculum Development.

[17] Mc. Taggart, R., \& Kemmis, S. (1990). The Action Research Planner. Melbourne: Deakin University.

[18] Iskandar. (2009). Metodologi Penelitian Kualitatif. Jakarta: Gaung Persada Press.

[19] Yonny, A. (2010). Menyusun Penelitian Tindakan Kelas. Yogyakarta: Penerbit Familia.

[20] Jihad, A., dkk. (2012). Evaluasi Pembelajaran. Yogyakarta: Penerbit Multi Pressindo.

[21] Rosdianto, H. (2017). Pengaruh Model Generative Learning Terhadap Hasil Belajar Ranah Kognitif Siswa Pada Materi Hukum Newton. Jurnal Pendidikan Fisika dan Keilmuan (JPFK), 3(2), 66-69.

[22] Herniati, R., Sulistri, E., \& Rosdianto, H. (2017). Penerapan Model Predict Observe Explain Dengan Pendekatan Learning by Doing Untuk Meningkatkan Hasil Belajar Siswa. Jurnal Fisika FLUX, 14(2): 120124.

[23] Arikunto, S. (2006). Penelitian Tindakan Kelas. Jakarta: PT. Buni Aksara.

[24] Slavin, R.E. (2015). Cooperative Learning in Elementary Schools. Education 3-13, 43: 5-14.

[25] Johnson, D.W., \& Johnson, R.T. (1991). Learning Together and Alone. Allin and Bacon: Massa Chussetts.

[26] Trianto (2011). Panduan Lengkap Penelitian Tindakan Kelas (Classroom Action Research (Teori dan Praktek). Jakarta: Penerbit Prestasi Pustakaraya. 